\title{
Tatalaksana Penyakit Jantung Bawaan
}

\author{
Mulyadi M. Djer, Bambang Madiyono
}

\begin{abstract}
Penyakit jantung bawaan (PJB) merupakan kelainan jantung yang sudah didapat sejak lahir. Manifestasinya klinis bergantung dari berat ringan penyakit, mulai dari asimtomatis sampai dengan adanya gejala gagal jantung pada neonatus. Dengan berkembangnya teknologi, terutama dengan ditemukannya ekokardiografi, banyak kelainan jantung bawaan asimtomatis yang dapat dideteksi. Tata laksana meliputi non-bedah dan bedah. Tata laksana non-bedah meliputi pengobatan medikamentosa dan kardiologi intervensi, sedangkan tata laksana bedah meliputi bedah paliatif dan operasi definitif. Tujuan tata laksana medikamentosa dan bedah paliatif adalah untuk mengatasi gejala klinis akibat komplikasi PJB sambil menunggu waktu yang tepat untuk dilakukan operasi definitif. Akhir-akhir ini telah dikembangkan kardiologi intervensi, suatu tindakan yang memberi harapan baru bagi pasien PJB tanpa operasi, namun saat ini biayanya masih cukup tinggi.
\end{abstract}

Kata kunci: penyakit jantung bawaan, bedah jantung, kardiologi intervensi, ekokardiografi

P enyakit jantung bawaan (PJB) merupakan bentuk kelainan jantung yang sudah didapatkan sejak bayi baru lahir. Manifestasi klinis kelainan ini bervariasi dari yang paling ringan sampai berat. Pada bentuk yang ringan, sering tidak ditemukan gejala, dan tidak ditemukan kelainan pada pemeriksaan klinis. Sedangkan pada PJB berat, gejala sudah tampak sejak lahir dan memerlukan tindakan segera. Dengan berkembangnya teknologi, khususnya ekokardiografi, banyak kelainan jantung yang sebelumnya tidak dapat dideteksi dengan pemeriksaan fisis dan penunjang biasa, EKG, radiologi dengan menggunakan alat ini dapat dideteksi dengan mudah. ${ }^{1-4}$

Angka kejadian PJB di Indonesia adalah 8 tiap 1000 kelahiran hidup. ${ }^{1}$ Jika jumlah penduduk

Staff pengajar sub bagian kardiologi, Bagian Ilmu Kesehatan Anak FKUI - RSCM (Dr. Mulyadi M. Djer Sp.A dan Prof. DR. Bambang Madiyono SpAK, SpJP)

Alamat korespondensi:

Dr. Mulyadi, Sp.A.

Bagian Ilmu Kesehatan Anak FKUI-RSCM, Jl. Salemba 6, Jakarta 10430. Tel. 392 5901, 315 5742, Fax. 3907743.
Indonesia 200 juta, dan angka kelahiran 2\%, maka jumlah penderita PJB di Indonesia bertambah 32000 bayi setiap tahun. Kendala utama dalam menangani anak dengan PJB adalah tingginya biaya pemeriksaan dan operasi. Pengalaman kami di poliklinik Kardiologi RSCM, mendapatkan sebagian besar anak dengan PJB yang berobat berasal dari keluarga yang tidak mampu. ${ }^{2}$ Makalah ini membahas tentang hemodinamik, klasifikasi, etiologi, manifestasi klinis, diagnosis, tata laksana, komplikasi PJB serta perkembangan mutakhir di bidang kardiologi.

\section{Hemodinamik}

Jantung sebagai pompa, berfungsi memompakan darah ke seluruh tubuh untuk memenuhi tubuh akan kebutuhan metabolisme.

Sebagai pompa darah, kinerja jantung dipengaruhi oleh beban diastolik (preload), beban sistolik (afterload), kontraktilitas dan laju jantung. Secara anatomis jantung terdiri dari 4 ruang yang terpisah oleh sekat yaitu 2 serambi (atrium) dan 2 bilik (ventrikel). Pembuluh nadi utama (aorta) keluar dari bilik kiri, sedangkan pembuluh nadi paru (arteri pulmonal) 
keluar dari bilik kanan jantung. Pembuluh balik besar (vena kava) yang menampung darah dari seluruh tubuh, masuk ke dalam atrium kanan sedangkan pembuluh balik paru (vena pulmonalis) masuk ke dalam atrium kiri.

Darah yang mengandung oksigen tinggi dari ventrikel kiri, melalui aorta akan dipompakan ke seluruh tubuh untuk memenuhi metabolisme tubuh. Selanjutnya darah dengan saturasi rendah yang berasal dari seluruh tubuh melalui vena kava masuk ke dalam atrium kanan yang kemudian masuk ke dalam ventrikel kanan untuk selanjutnya dipompakan ke paru melalui arteri pulmonal untuk dibersihkan di paru. Darah yang mengandung oksigen tinggi dari paru, melalui vena pulmonalis dialirkan ke atrium kiri, kemudian dialirkan ke ventrikel kiri untuk selanjutnya dipompakan ke seluruh tubuh.

Penyakit jantung bawaan dapat berupa defek pada sekat yang membatasi ke dua atrium atau ventrikel sehingga terjadi percampuran darah pada tingkat atrium atau ventrikel, misalnya defek septum ventrikel atau defek septum atrium. Dapat juga terjadi pada pembuluh darah yang tetap terbuka yang seharusnya menutup setelah lahir seperti pada duktus arteriosus persisten. Kelainan lain berupa kelainan yang lebih kompleks seperti tertukarnya posisi aorta dan arteri pulmonalis atau kelainan muara vena pulmonalis. ${ }^{1}$

\section{Klasifikasi Penyakit Jantung Bawaan}

Secara garis besar penyakit jantung bawaan dibagi 2 kelompok, yaitu penyakit jantung bawaan sianotik dan penyakit jantung bawaan nonsianotik. Penyakit jantung bawaan sianotik ditandai oleh adanya sianosis sentral akibat adanya pirau kanan ke kiri, sebagai contoh tetralogi Fallot, transposisi arteri besar, atresia trikuspid. ${ }^{1}$

Termasuk dalam kelompok penyakit jantung bawaan nonsianotik adalah penyakit jantung bawaan dengan kebocoran sekat jantung yang disertai pirau kiri ke kanan di antaranya adalah defek septum ventrikel, defek septum atrium, atau tetap terbukanya pembuluh darah seperti pada duktus arteriosus persisten. Selain itu penyakit jantung bawaan nonsianotik juga ditemukan pada obtruksi jalan keluar ventrikel seperti stenosis aorta, stenosis pulmonal dan koarktasio aorta. ${ }^{1}$

\section{Etiologi}

Pada sebagian besar kasus, penyebab PJB tidak diketahui. Pelbagai jenis obat, penyakit ibu, pajanan terhadap sinar Rontgen, diduga merupakan penyebab eksogen penyakit jantung bawaan. Penyakit rubela yang diderita ibu pada awal kehamilan dapat menyebabkan PJB pada bayi. Di samping faktor eksogen terdapat pula faktor endogen yang berhubungan dengan kejadian PJB. Pelbagai jenis penyakit genetik dan sindrom tertentu erat berkaitan dengan kejadian PJB seperti sindrom Down, Turner, dan lain-lain. ${ }^{1,5}$

\section{Manifestasi Klinis}

Gangguan hemodinamik akibat kelainan jantung dapat memberikan gejala yang menggambarkan derajat kelainan. Adanya gangguan pertumbuhan, sianosis, berkurangnya toleransi latihan, kekerapan infeksi saluran napas berulang, dan terdengarnya bising jantung, dapat merupakan petunjuk awal terdapatnya kelainan jantung pada seorang bayi atau anak. ${ }^{1}$

a. Gangguan pertumbuhan. Pada PJB nonsianotik dengan pirau kiri ke kanan, gangguan pertumbuhan timbul akibat berkurangnya curah jantung. Pada PJB sianotik, gangguan pertumbuhan timbul akibat hipoksemia kronis. Gangguan pertumbuhan ini juga dapat timbul akibat gagal jantung kronis pada pasien PJB.

b. Sianosis. Sianosis timbul akibat saturasi darah yang menuju sistemik rendah. Sianosis mudah dilihat pada selaput lendir mulut, bukan di sekitar mulut. Sianosis akibat kelainan jantung ini (sianosis sentral) perlu dibedakan pada sianosis perifer yang sering didapatkan pada anak yang kedinginan. Sianosis perifer lebih jelas terlihat pada ujungujung jari.

c. Toleransi latihan. Toleransi latihan merupakan petunjuk klinis yang baik untuk menggambarkan status kompensasi jantung ataupun derajat kelainan jantung. Pasien gagal jantung selalu menunjukkan toleransi latihan berkurang. Gangguan toleransi latihan dapat ditanyakan pada orangtua dengan membandingkan pasien dengan anak sebaya, apakah pasien cepat lelah, napas 
menjadi cepat setelah melakukan aktivitas yang biasa, atau sesak napas dalam keadaan istirahat. Pada bayi dapat ditanyakan saat bayi menetek. Apakah ia hanya mampu minum dalam jumlah sedikit, sering beristirahat, sesak waktu mengisap, dan berkeringat banyak. Pada anak yang lebih besar ditanyakan kemampuannya berjalan, berlari atau naik tangga. Pada pasien tertentu seperti pada tetralogi Fallot anak sering jongkok setelah lelah berjalan.

d. Infeksi saluran napas berulang. Gejala ini timbul akibat meningkatnya aliran darah ke paru sehingga mengganggu sistem pertahanan paru. Sering pasien dirujuk ke ahli jantung anak karena anak sering menderita demam, batuk dan pilek. Sebaliknya tidak sedikit pasien PJB yang sebelumnya sudah diobati sebagai tuberkulosis sebelum di rujuk ke ahli jantung anak.

e. Bising jantung. Terdengarnya bising jantung merupakan tanda penting dalam menentukan penyakit jantung bawaan. Bahkan kadang-kadang tanda ini yang merupakan alasan anak dirujuk untuk dilakukan pemeriksaan lebih lanjut. Lokasi bising, derajat serta penjalarannya dapat menentukan jenis kelainan jantung. Namun tidak terdengarnya bising jantung pada pemeriksaan fisis, tidak menyingkirkan adanya kelainan jantung bawaan. Jika pasien diduga menderita kelainan jantung, sebaiknya dilakukan pemeriksaan penunjang untuk memastikan diagnosis.

\section{Diagnosis}

Diagnosis penyakit jantung bawaan ditegakkan berdasarkan pada anamnesis, pemeriksaan fisis, pemeriksaan penunjang dasar serta lanjutan. Pemeriksaan penunjang dasar yang penting untuk penyakit jantung bawaan adalah foto rontgen dada, elektrokardiografi, dan pemeriksaan laboratorium rutin. Pemeriksaan lanjutan (untuk penyakit jantung bawaan) mencakup ekokardiografi dan kateterisasi jantung. Kombinasi ke dua pemeriksaan lanjutan tersebut untuk visualisasi dan konfirmasi morfologi dan pato-anatomi masing-masing jenis penyakit jantung bawaan memungkinkan ketepatan diagnosis mendekati seratus persen. Kemajuan teknologi di bidang diagnostik kardiovaskular dalam dekade terakhir menyebabkan pergeseran persentase angka kejadian beberapa jenis penyakit jantung bawaan tertentu. Hal ini tampak jelas pada defek septum atrium dan transposisi arteri besar yang makin sering dideteksi lebih awal. ${ }^{1,6-8}$

Makin canggihnya alat ekokardiografi yang dilengkapi dengan Doppler berwarna, pemeriksaan tersebut dapat mengambil alih sebagian peran pemeriksaan kateterisasi dan angiokardiografi. Hal ini sangat dirasakan manfaatnya untuk bayi dengan PJB kompleks, yang sukar ditegakkan diagnosisnya hanya berdasarkan pemeriksaan dasar rutin dan sulitnya pemeriksaan kateterisasi jantung pada bayi. Ekokardiografi dapat pula dipakai sebagai pemandu pada tindakan septostomi balon transeptal pada transposisi arteri besar. Di samping lebih murah, ekokardiografi mempunyai keunggulan lainnya yaitu mudah dikerjakan, tidak menyakitkan, akurat dan pasien terhindar dari pajanan sinar X. Bahkan di rumah sakit yang mempunyai fasilitas pemeriksaan ekokardiografi, foto toraks sebagai pemeriksaan rutinpun mulai ditinggalkan. Namun demikian apabila di tangan seorang ahli tidak semua pertanyaan dapat dijawab dengan menggunakan sarana ini, pada keadaan demikian angiografi radionuklir dapat membantu. Pemeriksaan ini di samping untuk menilai secara akurat fungsi ventrikel kanan dan kiri, juga untuk menilai derasnya pirau kiri ke kanan. Pemeriksaan ini lebih murah daripada kateterisasi jantung, dan juga kurang traumatis.

Tingginya akurasi pemeriksaan ekokardiografi, membuat pemeriksaan kateterisasi pada tahun 1980 menurun drastis. Sarana diagnostik lain terus berkembang, misalnya digital substraction angiocardiography, ekokardiografi transesofageal, dan ekokardiografi intravaskular. Sarana diagnostik utama yang baru adalah magnetic resonance imaging, dengan dilengkapi modus cine sarana pemeriksaan ini akan merupakan andalan di masa mendatang. ${ }^{1,6-8}$

\section{Tatalaksana Penyakit Jantung Bawaan}

Dengan berkembangnya ilmu kardiologi anak, banyak pasien dengan penyakit jantung bawaan dapat diselamatkan dan mempunyai nilai harapan hidup yang lebih panjang. Umumnya tata laksana penyakit jantung bawaan meliputi tata laksana non-bedah dan 
tata laksana bedah. Tata laksana non-bedah meliputi tata laksana medikamentosa dan kardiologi intervensi. ${ }^{1,9,10}$

Tata laksana medikamentosa umumnya bersifat sekunder sebagai akibat komplikasi dari penyakit jantungnya sendiri atau akibat adanya kelainan lain yang menyertai. Dalam hal ini tujuan terapi medikamentosa untuk menghilangkan gejala dan tanda di samping untuk mempersiapkan operasi. Lama dan cara pemberian obat-obatan tergantung pada jenis penyakit yang dihadapi.

Hipoksemia, syok kardiogenik, dan gagal jantung merupakan tiga penyulit yang sering ditemukan pada neonatus atau anak dengan kelainan jantung bawaan. Perburukan keadaan umum pada dua penyulit pertama ada hubungannya dengan progresivitas penutupan duktus arterious, dalam hal ini terdapat ketergantungan pada tetap terbukanya duktus. Keadaan ini termasuk ke dalam golongan penyakit jantung bawaan kritis. Tetap terbukanya duktus ini diperlukan untuk (1) percampuran darah pulmonal dan sistemik, misalnya pada transposisi arteri besar dengan septum ventrikel utuh, (2) penyediaan darah ke aliran pulmonal, misalnya pada tetralogi Fallot berat, stenosis pulmonal berat, atresia pulmonal, dan atresia trikuspid, (3) penyediaan darah untuk aliran sistemik, misalnya pada stenosis aorta berat, koarktasio aorta berat, interupsi arkus aorta dan sindrom hipoplasia jantung kiri. Perlu diketahui bahwa penanganan terhadap penyulit ini hanya bersifat sementara dan merupakan upaya untuk'menstabilkan keadaan pasien, menunggu tindakan operatif yang dapat berupa paliatif atau koreksi total terhadap kelainan struktural jantung yang mendasarinya.

Jika menghadapi neonatus atau anak dengan hipoksia berat, tindakan yang harus dilakukan adalah (1) mempertahankan suhu lingkungan yang netral misalnya pasien ditempatkan dalam inkubator pada neonatus, untuk mengurangi kebutuhan oksigen, (2) kadar hemoglobin dipertahankan dalam jumlah yang cukup, pada neonatus dipertahankan di atas $15 \mathrm{~g} / \mathrm{dl}$, (3) memberikan cairan parenteral dan mengatasi gangguan asam basa, (4) memberikan oksigen menurunkan resistensi paru sehingga dapat menambah aliran darah ke paru, (5) pemberian prostaglandin E1 supaya duktus arteriosus tetap terbuka dengan dosis permulaan $0,1 \mu \mathrm{g} / \mathrm{kg} /$ menit dan bila sudah terjadi perbaikan maka dosis dapat diturunkan menjadi 0,05 $\mu \mathrm{g} / \mathrm{kg} / \mathrm{menit}$. Obat ini akan bekerja dalam waktu 10 30 menit sejak pemberian dan efek terapi ditandai dengan kenaikan $\mathrm{PaO}_{2}$ 15-20 mmHg dan perbaikan $\mathrm{pH}$. Pada PJB dengan sirkulasi pulmonal tergantung duktus arteriosus, duktus arteriosus yang terbuka lebar dapat memperbaiki sirkulasi paru sehingga sianosis akan berkurang. Pada PJB dengan sirkulasi sistemik yang tergantung duktus arteriosus, duktus arteriosus yang terbuka akan menjamin sirkulasi sistemik lebih baik. Pada transposisi arteri besar, meskipun bukan merupakan lesi yang bergantung duktus arteriosus, duktus arteriosus yang terbuka akan memperbaiki percampuran darah.

Pada pasien yang mengalami syok kardiogenik harus segera diberikan pengobatan yang agresif dan pemantauan invasif. Oksigen harus segera diberikan dengan memakai sungkup atau kanula hidung. Bila ventilasi kurang adekuat harus dilakukan intubasi endotrakeal dan bila perlu dibantu dengan ventilasi mekanis. Prostaglandin E1 $0,1 \mu \mathrm{g} / \mathrm{kg} /$ menit dapat diberikan untuk melebarkan kembali dan menjaga duktus arteriosus tetap terbuka. Obat-obatan lain seperti inotropik, vasodilator dan furosemid diberikan dengan dosis dan cara yang sama dengan tata laksana gagal jantung.

Pada pasien PJB dengan gagal jantung, tata laksana yang ideal adalah memperbaiki kelainan struktural jantung yang mendasarinya. Pemberian obat-obatan bertujuan untuk memperbaiki perubahan hemodinamik, dan harus dipandang sebagai terapi sementara sebelum tindakan definitif dilaksanakan. Pengobatan gagal jantung meliputi (1) penatalaksanaan umum yaitu istirahat, posisi setengah duduk, pemberian oksigen, pemberian cairan dan elektrolit serta koreksi terhadap gangguan asam basa dan gangguan elektrolit yang ada. Bila pasien menunjukkan gagal napas, perlu dilakukan ventilasi mekanis (2) pengobatan medikamentosa dengan menggunakan obat-obatan. Obatobat yang digunakan pada gagal jantung antara lain (a) obat inotropik seperti digoksin atau obat inotropik lain seperti dobutamin atau dopamin. Digoksin untuk neonatus misalnya, dipakai dosis $30 \mu \mathrm{g} / \mathrm{kg}$. Dosis pertama diberikan setengah dosis digitalisasi, yang kedua diberikan 8 jam kemudian sebesar seperempat dosis sedangkan dosis ketiga diberikan 8 jam berikutnya sebesar seperempat dosis. Dosis rumat diberikan setelah 8-12 jam pemberian dosis terakhir dengan dosis seperempat dari dosis digitalisasi. Obat inotropik isoproterenol dengan dosis $0,05-1 \mu \mathrm{g} / \mathrm{kg} /$ 
menit diberikan bila terdapat bradikardia, sedangkan bila terdapat takikardia diberikan dobutamin 5-10 $\mu \mathrm{g} /$ $\mathrm{kg} /$ menit atau dopamin bila laju jantung tidak begitu tinggi dengan dosis $2-5 \mu \mathrm{g} / \mathrm{kg} /$ menit. Digoksin tidak boleh diberikan pada pasien dengan perfusi sistemik yang buruk dan jika ada penurunan fungsi ginjal, karena akan memperbesar kemungkinan intoksikasi digitalis. (b) vasodilator, yang biasa dipakai adalah kaptopril dengan dosis $0,1-0,5 \mathrm{mg} / \mathrm{kg} / \mathrm{hari}$ terbagi $2-3$ kali per oral. Terakhir (c) diuretik, yang sering digunakan adalah furosemid dengan dosis $1-2 \mathrm{mg} / \mathrm{kg} /$ hari per oral atau intravena. ${ }^{1,9,10}$

\section{Bedah Jantung}

Kemajuan dalam bidang perinatologi memungkinkan bayi dengan keadaan umum yang buruk dapat bertahan hidup. Sementara itu perkembangan teknologi diagnostik telah mampu mendeteksi kelainan jantung secara dini pada bayi baru lahir, bahkan sejak dalam kandungan dengan ekokardiografi janin. Di dalam bidang bedah jantung, kemampuan untuk melakukan operasi ditunjang oleh (1) teknologi pintas jantung-paru yang sudah semakin aman untuk bayi dengan berat badan yang rendah, (2) tersedianya instrumen yang diperlukan, (3) perbaikan kemampuan unit perawatan intensif pasca bedah, dan (4) pengalaman tim dalam mengerjakan kasus yang rumit. ${ }^{6,11,12}$

Pada prinsipnya penanganan penyakit jantung bawaan harus dilakukan sedini mungkin. Koreksi definitif yang dilakukan pada usia muda akan mencegah terjadinya distorsi pertumbuhan jantung, juga mencegah terjadinya hipertensi pulmonal. Operasi paliatif saat ini masih banyak dilakukan dengan tujuan memperbaiki keadaan umum, sambil menunggu saat operasi korektif dapat dilakukan. Namun tindakan paliatif ini seringkali menimbulkan distorsi pertumbuhan jantung, di samping pasien menghadapi risiko operasi dua kali dengan biaya yang lebih besar pula. Oleh karena itu terus dilakukan upaya serta penelitian agar operasi jantung dapat dilakukan pada neonatus dengan lebih aman. Kecenderungan di masa mendatang adalah koreksi definitif dilakukan pada neonatus.

Bentuk operasi paliatif yang sering dikerjakan pada penyakit jantung bawaan antara lain (1) Banding arteri pulmonalis. Prosedur ini dilakukan dengan memasang jerat pita dakron untuk memperkecil diameter arteri pulmonalis. Banding arteri pulmonalis dilakukan pada kasus dengan aliran pulmonal yang berlebihan akibat pirau dari kiri ke kanan di dalam jantung seperti pada defek septum ventrikel besar, ventrikel kanan jalan keluar ganda tanpa stenosis pulmonal, defek septum atrioventrikular, transposisi arteri besar, dan lain-lain. (2) Pirau antara sirkulasi sistemik dengan pulmonal. Prosedur ini dilakukan pada kelainan dengan aliran darah paru yang sangat berkurang sehingga saturasi oksigen rendah, anak menjadi biru dan sering disertai asidosis. Jenis-jenis operasi pirau antara lain: (a) Blalock-Taussig klasik, yaitu membebaskan arteri subklavia dan menyambungkannya ke arteri pulmonalis kiri atau kanan, (b) Modifikasi Blalock-Taussig, memasang pipa Gore-Tex antara arteri subklavia dengan arteri pulmonalis kanan atau kiri, (c) Pirau sentral, membuat hubungan antara aorta dengan arteri pulmonalis (Waterson, Potts, dengan Gore-Tex) dan (d) Pirau antara vena kava superior dengan arteri pulmonalis (Glenn shunt atau bidirectional cavo-pulmonary shunt). (3) Septostomi atrium. Prosedur ini dilakukan pada bayi sampai usia 3 bulan, yakni dengan kateter balon melalui vena femoralis. Tindakan ini dapat dilakukan di ruang perawatan intensif dengan bimbingan ekokardiografi, atau dapat juga dikerjakan di ruangan kateterisasi jantung. Pada anak yang lebih besar, tindakan ini dilakukan menurut metode Blalock-Hanlon. Septostomi atrium dilakukan pada transposisi arteri besar untuk menambah percampuran darah, pada anomali parsial drainase v. pulmonalis untuk mengurangi bendungan v. pulmonalis, dan pada atresia trikuspid untuk mengurangi bendungan vena sistemik.

Kemajuan yang pesat dalam pembedahan memungkinkan dilakukannya tindakan korektif pada penyakit jantung bawaan. Tindakan pembedahan korektif ini terutama dilakukan setelah ditemukan rancang-bangun oksigenator yang aman, khususnya pada bayi kecil. Metode yang banyak dipakai adalah "henti sirkulasi", sehingga lapangan operasi menjadi bersih dari genangan darah dan tidak terganggu oleh kanula vena. Ada beberapa kelainan jantung bawaan yang memerlukan pembedahan korektif pada usia neonatus misalnya anomali total drainase vena pulmonalis dengan obstruksi, transposisi tanpa defek septum ventrikel, trunkus arteriosus dengan gagal jantung. Sebagian lagi pembedahan dapat ditunda sampai usia lebih besar, atau memerlukan operasi paliatif untuk menunggu saat yang tepat untuk koreksi. ${ }^{6,11,12}$ 


\section{Kardiologi Intervensi}

Salah satu prosedur pilihan yang sangat diharapkan di bidang kardiologi anak adalah kardiologi intervensi nonbedah melalui kateterisasi pada pasien penyakit jantung bawaan. Tindakan ini selain tidak traumatis dan tidak menimbulkan jaringan parut, juga diharapkan biayanya lebih murah. Meskipun kardiologi intervensi telah dikembangkan sejak tahun 1950, namun hingga pertengahan tahun 1980 belum semua jenis intervensi trans-kateter dapat dikerjakan pada anak, termasuk balloon atrial septostomy. ${ }^{13-15}$

Di Indonesia kardiologi intervensi pada anak dimulai pada tahun 1989, diawali dengan kemajuan di bidang balloon mitral valvotomy yang dilakukan di Rumah Sakit Jantung Harapan Kita Jakarta pada kasus stenosis katup mitral. Kemudian disusul prosedur balloon atrial septostomy pada tahun $1989 .{ }^{13}$ Pada tahun yang sama balloon pulmonal valvotomy mulai dikerjakan. Selanjutnya prosedur intervensi yang dilakukan adalah oklusi duktus arteriosus persisten dengan coil Gianturco yang baru dimulai 3 tahun terakhir. Di Indonesia sejauh ini baru 3 pusat pelayanan kardiologi anak yang melakukan intervensi kardiologi, yaitu RS Jantung Harapan Kita dan RSUP Cipto Mangunkusumo di Jakarta dan RSUP Dr. Soetomo Surabaya. Berbagai jenis kardiologi intervensi antara lain adalah:

- Balloon atrial septostomy (BAS) adalah prosedur rutin yang dilakukan pada pasien yang memerlukan percampuran darah lebih baik, misalnya TAB (transposisi arteri besar) dengan septum ventrikel yang utuh. Prosedur ini dilakukan dengan membuat lubang di septum interatrium, dan biasanya dilakukan di ruang rawat intensif dengan bimbingan ekokardiografi. Di RSJHK telah dilakukan 64 prosedur BAS dan umumnya prosedur ini berhasil menciptakan lubang di septum interatrium dan memperbaiki kondisi pasien. Namun sebanyak 3 pasien mengalami kegagalan karena sulitnya kateter balon memasuki foramen ovale paten pada pasien dengan septum atrium yang melengkung atau atrium kiri yang kecil. Satu pasien meninggal karena perforasi di daerah vena pulmonalis.

- Balloon pulmonal valvuloplasty (BPV) kini merupakan prosedur standar untuk melebarkan katup pulmonal yang menyempit, dan ternyata hasilnya cukup baik, dan biayanya juga jauh lebih rendah dibandingkan dengan operasi. Di RSJHK, prosedur ini sejak tahun 1985 telah dilakukan pada 48 kasus stenosis katup pulmonal yang seringkali disertai stenosis infundibulum. Umumnya pasca BVP kondisi fisik pasien bertambah baik. Penyulit terjadi pada 1 kasus karena muskulus papilaris katup trikuspid putus saat tindakan dikerjakan sehingga memerlukan pembedahan emergensi.

- Balloon mitral valvotomy (BMV) umumnya dikerjakan pada kasus stenosis katup mitral akibat demam reumatik.

- Balloon aortic valvuloplasty (BAV) belum dilakukan rutin dan kasusnya juga jarang dijumpai. Prosedur ini baru dikerjakan pada 2 kasus.

- Penyumbatan duktus arteriosus menggunakan coil Gianturco juga dikerjakan pada beberapa kasus, namun belum dianggap rutin karena harga coil dan peralatan untuk memasukkan coil tersebut cukup mahal. Tindakan ini telah dilakukan pada 12 kasus dengan duktus arteriosus persisten, kesemuanya memakai coil Gianturco. Penyulit hemolisis terjadi pada 3 kasus. ${ }^{13}$

- Di Subbagian Kardiologi FKUI/RSCM tindakan intervensi kardiologi yang pernah dilakukan adalah dilatasi balon dan pemasangan stent pada arteri renalis pada pasien arteritis Takayasu. Pasca tindakan kondisi pasien baik dan tekanan darah turun. Tindakan lainnya seperti penutupan DSA (defek septum atrium), DSV (defek septum ventrikel), fistula koroner, MAPCA (major aortico - pulmonary collateral arteries) belum pernah dilakukan. ${ }^{13}$

- Di Institut Jantung Negara Kuala Lumpur Malaysia, penutupan duktus arteriosus persisten dilakukan dengan menggunakan umbrella, coil dan $\mathrm{ADO}$ (amplatzer ductal occluder); sedangkan untuk defek septum atrium ditutup dengan menggunakan ASO (amplatzer septal occluder). ${ }^{14}$ Di Royal Children,s Hospital Melbourne, Australia telah dilakukan penutupan defek septum ventrikel tipe muskular yang sulit dioperasi dengan amplatzer device. $^{8}$

\section{Komplikasi}

Komplikasi yang dapat terjadi pada penyakit jantung bawaan antara lain ${ }^{1}$ 
1. Sindrom Eisenmenger. Komplikasi ini terjadi pada PJB non-sianotik yang menyebabkan aliran darah ke paru yang meningkat. Akibatnya lama kelamaan pembuluh kapiler di paru akan bereaksi dengan meningkatkan resistensinya sehingga tekanan di arteri pulmonal dan di ventrikel kanan meningkat. Jika tekanan di ventrikel kanan melebihi tekanan di ventrikel kiri maka terjadi pirau terbalik dari kanan ke kiri sehingga anak mulai sianosis. Tindakan bedah sebaiknya dilakukan sebelum timbul komplikasi ini.

2. Serangan sianotik. Komplikasi ini terjadi pada PJB sianotik. Pada saat serangan anak menjadi lebih biru dari kondisi sebelumnya, tampak sesak bahkan dapat timbul kejang. Kalau tidak cepat ditanggulangi dapat menimbulkan kematian.

3. Abses otak. Abses otak biasanya terjadi pada PJB sianotik. Biasanya abses otak terjadi pada anak yang berusia di atas 2 tahun. Kelainan ini diakibatkan adanya hipoksia dan melambatnya aliran darah di otak. Anak biasanya datang dengan kejang dan terdapat defisit neurologis.

\section{Apa yang Harus Dilakukan bila Menghadapi Pasien atau Dicurigai Menderita PJB?}

Bila menghadapi seorang anak yang dicurigai menderita penyakit jantung bawaan, yang perlu dilakukan adalah

1. Menempatkan pasien khususnya neonatus pada lingkungan yang hangat, dapat dilakukan dengan membedong atau menempatkannya pada inkubator.

2. Memberikan oksigen

3. Memberikan cairan yang cukup dan mengatasi gangguan elektrolit serta asam basa.

4. Mengatasi kegawatan dengan menggunakan obat-obatan jika terdapat tanda tanda seperti gagal jantung, serangan sianotik, renjatan kardiogenik.

5. Menegakkan diagnosis/jenis kelainan yang diderita. Jika tidak memiliki fasilitas, pasien dapat dirujuk ke tempat yang fasilitasnya lengkap terutama tersedia alat ekokardiografi. Tata laksana PJB dan edukasi yang disampaikan ke orangtua pasien, tergantung dari jenis kelainan yang ada.
6. Pemantauan yang cermat untuk mengetahui adanya komplikasi, sehingga dapat dilakukan tindakan sebelum komplikasi ada.

\section{Penutup}

Ketelitian dan kecermatan sangat diperlukan dalam menangani bayi atau anak dengan penyakit jantung bawaan. Semua jajaran tenaga kesehatan mulai dari paramedis, dokter umum, dokter keluarga, dokter spesialis anak, dokter spesialis jantung dan konsultan kardiologi anak serta dokter spesialis bedah jantung, semuanya mempunyai andil dalam membentuk jaringan pelayanan kardiologi anak terpadu yang saling melengkapi dalam satu sistem rujukan, dalam rangka menuju pelayanan kesehatan komprehensif.

\section{Daftar Pustaka}

1. Allen HD, Franklin WH, Fontana ME. Congenital heart disease: untreated and operated. Dalam: Emmanoulides GC, Riemenschneider TA, Allen HD, Gutgesell HP, penyunting. Moss and Adams heart disease in infants, children, and adolescents. Edisi ke-5. Baltimore: Williams \& Wilkins; 1995. h. 657-64.

2. Madiyono B. Kardiologi anak masa lampau, kini dan masa mendatang: perannya dalam pencegahan dan penanggulangan penyakit kardiovaskular. Pidato pengukuhan guru besar tetap dalam bidang ilmu kesehatan anak, FKUI, Jakarta, 11 Juni 1997. Jakarta: Lembaga Penerbit UI; 1997.

3. Rahayoe AU. Pelayanan penderita penyakit jantung bawaan di Indonesia. Perkembangan, permasalahan dan antisipasi di masa depan. Dalam: Putra ST, Roebiono PS, Advani N, penyunting. Penyakit jantung bawaan pada bayi dan anak. Jakarta: Forum Ilmiah Kardiologi Anak Indonesia; 1998. h. 1-17.

4. Rilantono LI. Kardiologi anak: tuntutan dan perkembangannya. Dalam: Putra ST, Advani N, Rahayoe AU, penyunting. Dasar-dasar diagnosis dan tata laksana penyakit jantung bawaan pada anak. Jakarta: Forum Ilmiah Kardiologi Anak Indonesia; 1996. h. 10-21.

5. Sastroasmoro S, Nurhamzah W, Madiyono B, Oesman IN, Putra ST. Association between maternal hormone exposure and the development of congenital heart disease of the truncal type A. A case-control study. Paediatr Indones 1993; 33:291-300.

6. Emmanouilides GC. The development of pediatric cardiology: history milestones. Dalam: Emmanoulides GC, Riemenschneider TA, Allen HD, Gutgesell HP, penyunting. Moss and Adams heart disease in infants, children, and adolescents. Edisi ke-5. Baltimore: 
Williams \& Wilkins; 1995. h. xxi-iv.

7. Rahayuningsih SE, Rahayoe AU, Harimurti GM, Roebiono PS, Rachmat J. Diagnostic accuracy of echocardiography in isolated ventricular septal defect. Indones J Pediatr Cardiol 1999,1:19-21.

8. Wilkinson JL. Practical guidelines to early detection of congenital heart disease in the newborn period. Indones J Pediatr Cardiol 1999,1:30-9.

9. Oesman IN. Tata laksana penyakit jantung bawaan dengan penyulit pada neonatus. Dalam: Sastroasmoro S, Madiyono B, Putra ST, penyunting. Pengenalan dini dan tata laksana penyakit jantung bawaan pada neonatus. Pendidikan tambahan berkala bagian ilmu kesehatan anak FKUI ke-32, 1994. Jakarta: Gaya Baru; 1994. h. 168-76.

10. Sastroasmoro S, Rahayuningsih SE. Tata laksana medis neonatus dengan penyulit jantung bawaan kritis. Dalam: Putra ST, Roebiono PS, Advani N, penyunting. Penyakit jantung bawaan pada bayi dan anak. Jakarta: Forum Ilmiah Kardiologi Anak Indonesia; 1998. h. 147-56.

11. Racmat J. Perkembangan bedah jantung di Indonesia: perhatian khusus pada penyakit jantung bawaan. Dalam: Putra ST, Advani N, Rahayoe AU, penyunting. Dasardasar diagnosis dan tata laksana penyakit jantung bawaan pada anak. Jakarta: Forum Kardiologi Anak Indonesia; 1996. h. 23-31.

12. Rachmat J. Pembedahan jantung pada neonatus. Dalam: Sastroasmoro S, Madiyono B, Putra ST, penyunting. Pengenalan dini dan tata laksana penyakit jantung bawaan pada neonatus. Pendidikan tambahan berkala bagian ilmu kesehatan anak FKUI ke-32, 1994. Jakarta: Gaya Baru; 1994. h. 213-24.

13. Haryono N. Kardiologi intervensi pada penyakit jantung bawaan: pengalaman di Indonesia. Dalam: Putra ST, Roebiono PS, Advani N, penyunting. Penyakit jantung bawaan pada bayi dan anak. Jakarta: Forum Ilmiah Kardiologi Anak Indonesia; 1998. h. 217-9.

14. Alwi M. Interventional cardiology for newborn with critical pulmonary stenosis or pulmonary atresia. Indones J Pediatr Cardiol 1998; 1:10-3.

15. Rao PS. Interventional pediatric cardiology: state of the art and future direction. Pediatr Cardiol 1997; 19:107-24. 